\section{SOI: 1.1/TAS DOI: 10.15863/TAS International Scientific Journal Theoretical \& Applied Science}

p-ISSN: 2308-4944 (print)

e-ISSN: 2409-0085 (online)

Year: 2017

Issue: 05

Volume: 49

Published: $15.05 .2017 \quad$ http://T-Science.org

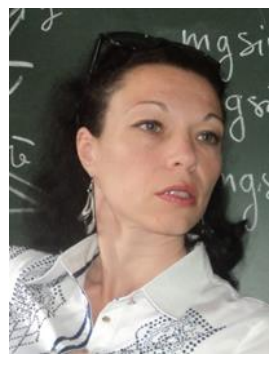

Tetiana P. Golub

$\mathrm{PhD}$, Associate Professor, National Technical University of Ukraine "Igor Sikorsky Kyiv Polytechnic Institute"

SECTION 31. Economic research, finance, innovation, risk management.

\title{
NUCLEAR POWER IN SUSTAINABLE DEVELOPMENT OF ENERGY INDUSTRY
}

Abstract: The article deals with the production of nuclear power as a sustainable energy technology, with modern state, advantages, and problems of nuclear industry development, resource provision, as well as global trends in nuclear power industry.

Key words: energy, nuclear power, nuclear reactor, nuclear power plant, sustainable development, uranium.

Language: English

Citation: Golub TP (2017) NUCLEAR POWER IN SUSTAINABLE DEVELOPMENT OF ENERGY INDUSTRY. ISJ Theoretical \& Applied Science, 05 (49): 39-47.

Soi: http://s-o-i.org/1.1/TAS-05-49-8 Doi: crossef https://dx.doi.org/10.15863/TAS.2017.05.49.8

\section{Introduction}

At the modern stage of mankind development the problem of resource-ecological safety of civilization existence has become extremely acute. To a greater extent, the reason for this is the extraction, production and use of energy.

The viability of modern civilization is based on non-renewable processes and is inextricably linked to the ever increasing production and consumption of electricity and various fuels for all kinds of vehicles. Resources of raw materials for their production (oil, gas, coal), no matter how great they now seem, ensure the existence of this civilization without serious political and economic upheavals for about 50 years, not to mention unpredictable changes in the functioning of the biosphere as a whole, local environmental disasters and climate change.

No political and economic reforms will solve the impending problems if they do not have effective energy industry, which is the heart of the economy. It is necessary to develop and implement new principles and methods for obtaining energy without large-scale intrusion into biospheric cycles. It is necessary to change attitudes towards values, in order to stop taking resources from the Earth and future generations practically for free to enrich individual states and people.

The public's relation to natural resources underlies the definition of the sustainability of society. Society can be sustainable if the rate of consumption of renewable resources does not exceed the rate of their recovery.
Advanced nuclear power will release organic resources to meet humanity's needs for chemical energy, clothing, food, building materials, etc.

Stocks of nuclear fuel finding no other application than energy, are sufficient to solve problems of harmonization of human society and the biosphere on the way to its transition to the noosphere without fuss and political tension. In addition, nuclear fuel does not burn, it turns into fission products, among which are valuable for the technogenic civilization nuclides from alkali metals to noble metals and gases.

It is worth noting that nuclear power is now increasingly being considered as a quasi-renewable energy technology. This is due to the fact that the properly organized structure of nuclear fuel in the mode of closing the fuel cycle for actinides (thorium, uranium, plutonium, etc.) can work with constant reproduction and even an increase in the necessary degree of the neutron potential of the system. Fuel resources (uranium) in this case are practically unlimited and in the structure of nuclear power, a system of high-temperature nuclear reactors capable of efficiently producing hydrogen from water can be created.

In a new energy system that is acceptable for long-term and large-scale use, the nuclear power plant can fulfill the role of not only an effective energy source, but also take over the functions to maintain (control) the required level of $\mathrm{CO}_{2}$ emissions into the atmosphere and the required level of radioactive radiation. And a part of the funds 
received due to taking into account the relevant externalities in organic energy for the sake of extending its life and increasing its own efficiency should be aimed at creating a nuclear fuel corresponding to the needs of sustainable development.

In order the nuclear power to really help humanity to cope with the problems of sustainable supply of energy, it must become large-scale, i.e. it must be multi-component both in reactor types, and in the capacity of single units, and in the degree of autonomy of nuclear power plants.

The sustainability of the nuclear power development is determined by the preservation of the accumulated potential of knowledge, the experimental and theoretical base, technologies and industries.

The world economy is now in a transitional state and the future of civilization, the main wealth of which are people and natural resources, is associated with the transition to a new technological and economic order.

The basis of the global economy should include the global energy that meets the requirements of resistance to various disturbances (natural, political, economic), reliability, security, acceptability (ecological, resource, economic, psychological ...) as an essential element.

\section{Discussion}

Despite the ongoing debate concerning the nuclear power plants operational risks the development of world nuclear power industry is characterized by positive trends recently. The active construction of new and modernization of existing reactors in many countries evidence it. The nuclear power currently accounts for $11.5 \%$ of global electricity and as predicted by the International Energy Agency (IEA), its share will continue to grow. Plans for large-scale development of nuclear energy (especially in certain regions of the world) are due to several reasons:

Primary energy consumption by fuel

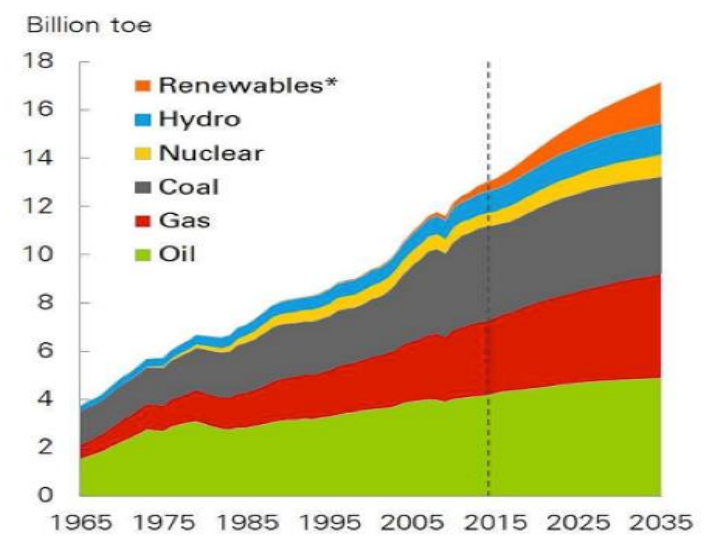

- increasing demand for energy supply due to the constant increase in population in the world and the rapid industrialization of production;

- increased competition for access to raw materials markets;

- exhaustion of reserves of traditional energy sources and the inevitable rise in their prices, and political instability in countries exporting oil and gas;

- the need to protect the environment in terms of greenhouse gas emissions that are causing "global warming";

- desire to create energy resources independent from external factors.

However, there are objective factors that significantly impede the development of the industry. First of all, these are the accidents at power plants that form negative public opinion and promote the adoption of appropriate policy decisions in the nuclear field. Furthermore, there is a necessity to address safety problems of nuclear power in terms of its impact on people and the environment, as well as problems of spent nuclear fuel.

Since the 2000s nuclear power is at the stage of recovery, largely due to the large-scale construction of nuclear power plants in the countries of the AsiaPacific region. The world celebrated the accelerated closure of old nuclear power plants, increasing demands on the state and international regulation of safety of the industry. However, the accident at the nuclear power plant "Fukushima" in Japan in 2011 added certain adjustments that negatively affected the projected rate of the industry development. Certainly, fossil fuels (oil, natural gas and coal) continue to satisfy the needs of most of the world, as no other energy source can compete with them in the availability, efficiency and scale. However, among nonfussil fuels the share of nuclear energy in the global energy consumption is predicted to slowly, but growing - from $4.5 \%$ in 2014 to $5.2 \%$ in 2035 (Figure 1 - Primary Energy Consumption by Fuel, and Shares of Primary Energy).

Shares of primary energy

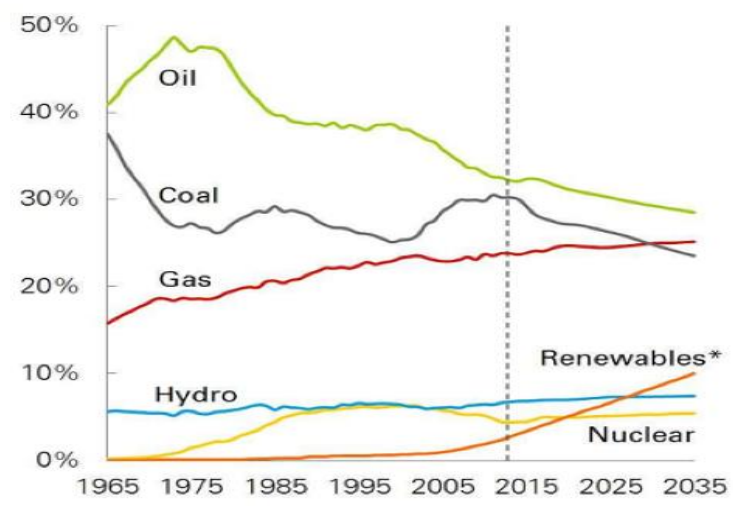

Figure 1 - Primary Energy Consumption by Fuel, and Shares of Primary Energy [from Annual Energy Outlook 2017] [1]

ISPC Technology and progress, Philadelphia, USA 


\begin{tabular}{|c|c|c|c|c|c|c|}
\hline Impact Factor: & $\begin{array}{l}\text { ISRA (India) } \\
\text { ISI (Dubai, UAE } \\
\text { GIF (Australia) } \\
\text { JIF }\end{array}$ & $\begin{array}{l}=1.344 \\
=0.829 \\
=0.564 \\
=1.500\end{array}$ & $\begin{array}{l}\text { SIS (USA) } \\
\text { PИНЦ (Russia) } \\
\text { ESJI (KZ) } \\
\text { SJIF (Morocco) }\end{array}$ & $\begin{array}{l}=0.912 \\
=0.234 \\
=3.860 \\
=\mathbf{2 . 0 3 1}\end{array}$ & $\begin{array}{l}\text { ICV (Poland) } \\
\text { PIF (India) } \\
\text { IBI (India) }\end{array}$ & $\begin{array}{l}=6.630 \\
=1.940 \\
=4.260\end{array}$ \\
\hline
\end{tabular}

Recently, the number of requests to the International Atomic Energy Agency (IAEA), particularly from developing countries is rapidly increasing, as for providing them with technical specification for creating energy systems in which nuclear power plays an important role. According to the World Nuclear Association, at March 1 ${ }^{\text {st }}, 2017$, globally there have been 447 operating nuclear reactors, 59 reactors under construction, 164 reactors planned for construction and 350 reactors at the stage of proposals to build (Table 1 - Current and Planned Nuclear Reactors in the World). Of the total reactors in service, $81.5 \%$ are light-water-moderated reactors and light-water-cooled reactors, $11.2 \%$ are heavywater-moderated reactors and heavy-water-cooled reactors, $3.4 \%$ are light-water graphite-moderated reactors, and $3.4 \%$ are gas-cooled reactors. There are also 2 fast liquid-metal cooled reactors. Most nuclear power plants have been launched during the second half of $1960^{\text {th }}$ - beginning of $1980^{\text {th }}$. Thus the average age of the reactors operating in the world is 28.5 years. And the oldest one is located in Switzerland, and has been operating for 45 years.

Current and Planned Nuclear Reactors in the World

Table 1

(According to World Nuclear Association) [2]

\begin{tabular}{|c|c|c|c|c|c|c|}
\hline Country & $\begin{array}{c}\text { Nuclear } \\
\text { Electricity } \\
\text { Generation } \\
2015 \\
(\%)\end{array}$ & $\begin{array}{c}\text { Reactors } \\
\text { Operable } \\
1 \text { March } 2017 \\
\text { (No / MWe) }\end{array}$ & $\begin{array}{c}\text { Reactors } \\
\text { under } \\
\text { Construction } \\
1 \text { March } 2017 \\
\text { (No/ MWe) }\end{array}$ & $\begin{array}{c}\text { Reactors } \\
\text { Planned } \\
\text { March } 2017 \\
\text { (No / MWe) }\end{array}$ & $\begin{array}{c}\text { Reactors } \\
\text { Proposed } \\
\text { March 2017 } \\
\text { (No/MWe) }\end{array}$ & $\begin{array}{c}\text { Uranium } \\
\text { Required } \\
2016 \\
\text { (tonnes) }\end{array}$ \\
\hline Armenia & 34.5 & $1 / 376$ & $0 / 0$ & $1 / 1060$ & & 88 \\
\hline Belgium & 37.5 & 7 / 5943 & $0 / 0$ & $0 / 0$ & $0 / 0$ & 1015 \\
\hline Bulgaria & 31.3 & $2 / 1926$ & $0 / 0$ & $1 / 950$ & 0 & 327 \\
\hline Canada & 16.6 & $19 / 13553$ & $0 / 0$ & $2 / 1500$ & $3 / 3800$ & 1630 \\
\hline China & 3.0 & $36 / 32637$ & $21 / 23086$ & $40 / 45700$ & $139 / 160000$ & 5338 \\
\hline Czech & 32.5 & $6 / 3904$ & $0 / 0$ & $2 / 2400$ & $1 / 1200$ & 565 \\
\hline \multicolumn{7}{|l|}{ Republic } \\
\hline Finland & 33.7 & 4 / 2764 & $1 / 1700$ & $1 / 1200$ & $1 / 1500$ & 1126 \\
\hline France & 76.3 & $58 / 63130$ & $1 / 1750$ & $0 / 0$ & $1 / 1750$ & 9211 \\
\hline Germany & 14.1 & 10728 & $0 / 0$ & $0 / 0$ & $0 / 0$ & 1689 \\
\hline Hungary & 52.7 & $4 / 1889$ & $0 / 0$ & $2 / 2400$ & $0 / 0$ & 356 \\
\hline India & 3.5 & $22 / 6219$ & $5 / 3300$ & $20 / 18600$ & $44 / 51000$ & 997 \\
\hline Japan & 0.5 & 42 / 39952 & $2 / 2756$ & $9 / 12947$ & $3 / 4145$ & 680 \\
\hline $\begin{array}{c}\text { Korea RO } \\
\text { (South) }\end{array}$ & 31.7 & 25 / 23081 & $3 / 4200$ & $8 / 11600$ & $0 / 0$ & 5013 \\
\hline Russia & 18.6 & $35 / 26865$ & 7 / 5904 & $25 / 27755$ & $23 / 22800$ & 6264 \\
\hline Saudi Arabia & 0 & $0 / 0$ & $0 / 0$ & $0 / 0$ & $16 / 17000$ & 0 \\
\hline Slovakia & 55.9 & $4 / 1816$ & $2 / 942$ & $0 / 0$ & $1 / 1200$ & 917 \\
\hline South Africa & 47 & $2 / 1830$ & $0 / 0$ & $0 / 0$ & $8 / 9600$ & 304 \\
\hline Switzerland & 33.5 & $5 / 3333$ & $0 / 0$ & $0 / 0$ & $3 / 4000$ & 521 \\
\hline Turkey & 0 & $0 / 0$ & $0 / 0$ & $4 / 4800$ & $4 / 4500$ & 0 \\
\hline Ukraine & 56.5 & $15 / 13107$ & $0 / 0$ & $2 / 1900$ & $11 / 12000$ & 2251 \\
\hline UAE & 0 & $0 / 0$ & $4 / 5600$ & $0 / 0$ & $10 / 14400$ & 0 \\
\hline United & 18.9 & $15 / 8883$ & $0 / 0$ & $4 / 6100$ & $9 / 11800$ & 1734 \\
\hline \multicolumn{7}{|l|}{ Kingdom } \\
\hline USA & 19.5 & 99 / 99535 & $4 / 5000$ & $18 / 8312$ & $24 / 26000$ & 18161 \\
\hline WORLD & c 11,5 & 447 / 391,942 & $59 / 63,420$ & $\begin{array}{c}164 / \\
170,844\end{array}$ & $\begin{array}{c}350 \text { / } \\
395,300\end{array}$ & 63,404 \\
\hline
\end{tabular}

Recently nearly half of nuclear reactors in the world operate beyond designed service life. However, according to the International Atomic Energy Agency it is planed to extend the service life of 112 units. As an international experience corroborates, the extending designed service life of power units is caused by economic expediency and provides the required security level. According to the
World Nuclear Association, in 2016 [3] the first place in nuclear electricity production is occupied by the USA, France, and China. Besides, the structure of total electricity production in nuclear power accounted for a large proportion in some countries, thus in France - 72.3\%, Slovakia - 54.1\%, Ukraine $52.3 \%$, Belgium $-51.7 \%$, Sweden $-40.0 \%$. 


\begin{tabular}{|c|c|c|c|c|c|c|}
\hline Impact Factor: & $\begin{array}{l}\text { ISRA (India) } \\
\text { ISI (Dubai, UAE } \\
\text { GIF (Australia) } \\
\text { JIF }\end{array}$ & $\begin{array}{l}=1.344 \\
=0.829 \\
=0.564 \\
=1.500\end{array}$ & $\begin{array}{l}\text { SIS (USA) } \\
\text { PИНЦ (Russia } \\
\text { ESJI (KZ) } \\
\text { SJIF (Morocco }\end{array}$ & $\begin{array}{l}=0.912 \\
=0.234 \\
=3.860 \\
=\mathbf{2 . 0 3 1}\end{array}$ & $\begin{array}{l}\text { ICV (Poland) } \\
\text { PIF (India) } \\
\text { IBI (India) }\end{array}$ & $\begin{array}{l}=6.630 \\
=1.940 \\
=4.260\end{array}$ \\
\hline
\end{tabular}

Table 2

Nuclear Share of Electricity, by Countries

(According to World Nuclear Association) [3]

\begin{tabular}{|c|c|c|c|c|c|c|c|c|c|c|c|c|c|}
\hline \multirow[t]{2}{*}{$\begin{array}{c}\text { Country or } \\
\text { area }\end{array}$} & \multicolumn{11}{|c|}{ Nuclear share of electricity (\%) } & \multicolumn{2}{|c|}{$\begin{array}{c}\text { Nuclear electricity } \\
\text { production (billion } \\
\text { kWh) }\end{array}$} \\
\hline & 2006 & 2007 & 2008 & 2009 & 2010 & 2011 & 2012 & 2013 & 2014 & 2015 & 2016 & 2015 & 2016 \\
\hline Armenia & 42.0 & 43.5 & 39.4 & 45.0 & 39.4 & 33.2 & 26.6 & 29.2 & 30.7 & 34.5 & 31.4 & 2.6 & 2.2 \\
\hline Belgium & 54.4 & 54.1 & 53.8 & 51.7 & 51.1 & 54.0 & 51.0 & 52.1 & 47.5 & 37.5 & 51.7 & 24.8 & 41.3 \\
\hline Bulgaria & 43.6 & 32.1 & 32.9 & 35.9 & 33.1 & 32.6 & 31.6 & 30.7 & 31.8 & 31.3 & 35.0 & 14.7 & 15.8 \\
\hline Canada & 15.8 & 14.7 & 14.8 & 14.8 & 15.1 & 15.3 & 15.3 & 16.0 & 16.8 & 16.6 & 15.6 & 95.6 & 97.4 \\
\hline \multicolumn{14}{|l|}{ China: } \\
\hline - Mainland & 1.9 & 1.9 & 2.2 & 1.9 & 1.8 & 1.9 & 2.0 & 2.1 & 2.4 & 3.0 & 3.6 & 161.2 & 210.5 \\
\hline - Taiwan & 19.5 & \begin{tabular}{|l|}
19.3 \\
\end{tabular} & 17.1 & 20.7 & 19.3 & 19.0 & 18.4 & 19.1 & 18.9 & 16.3 & 13.7 & 36.5 & 30.5 \\
\hline Czech Rep & 31.5 & 30.3 & 32.5 & 33.8 & 33.3 & 33.0 & 35.3 & 35.9 & 35.8 & 32.5 & 29.4 & 25.3 & 22.7 \\
\hline Finland & 28.0 & 28.9 & 29.7 & 32.9 & 28.4 & 31.6 & 32.6 & 33.3 & 34.6 & 33.7 & 33.7 & 22.3 & 22.3 \\
\hline France & 78.1 & \begin{tabular}{|l|}
76.9 \\
\end{tabular} & 76.2 & 75.2 & 74.1 & 77.7 & 74.8 & 73.3 & 76.9 & 76.3 & 72.3 & 419.0 & 384.0 \\
\hline Germany & 31.8 & 25.9 & \begin{tabular}{|l|l|}
28.3 \\
\end{tabular} & 26.1 & 28.4 & 17.8 & 16.1 & 15.5 & 15.8 & 14.1 & 13.1 & 86.8 & 80.1 \\
\hline Hungary & 37.7 & 36.8 & 37.2 & 43.0 & 42.1 & 43.2 & 45.9 & 50.7 & 53.6 & 52.7 & 51.3 & 15.0 & 15.2 \\
\hline India & 2.6 & 2.5 & 2.0 & 2.2 & 2.9 & 3.7 & 3.6 & 3.5 & 3.5 & 3.5 & 3.4 & 34.6 & 35.0 \\
\hline Japan & 30.0 & 27.5 & 24.9 & 28.9 & 29.2 & 18.1 & 2.1 & 1.7 & 0 & 0.5 & 2.2 & 4.3 & 17.5 \\
\hline Korea, $\mathbf{S}$ & 38.6 & 35.3 & 35.6 & 34.8 & 32.2 & 34.6 & 30.4 & 27.6 & 30.4 & 31.7 & 30.3 & 157.2 & 154.2 \\
\hline Mexico & 4.9 & 4.6 & 4.0 & 4.8 & 3.6 & 3.6 & 4.7 & 4.6 & 5.6 & 6.8 & 6.2 & 11.2 & 10.3 \\
\hline Netherlands & 3.5 & 4.1 & 3.8 & 3.7 & 3.4 & 3.6 & 4.4 & 2.8 & 4.0 & 3.7 & 3.4 & 3.9 & 3.8 \\
\hline Pakistan & 2.7 & 2.3 & 1.9 & 2.7 & 2.6 & 3.8 & 5.3 & 4.4 & 4.3 & 4.4 & 4.4 & 4.3 & 5.1 \\
\hline Romania & 9.0 & 13.0 & 17.5 & 20.6 & 19.5 & 19.0 & 19.4 & 19.8 & 18.5 & 17.3 & 17.1 & 10.7 & 10.4 \\
\hline Russia & 15.9 & 16.0 & \begin{tabular}{|l|}
16.9 \\
\end{tabular} & 17.8 & 17.1 & 17.6 & 17.8 & 17.5 & 18.6 & 18.6 & 17.1 & 182.8 & 179.7 \\
\hline Slovakia & 57.2 & 54.3 & 56.4 & 53.5 & 51.8 & 54.0 & 53.8 & 51.7 & 56.8 & 55.9 & 54.1 & 14.1 & 13.7 \\
\hline Slovenia & 40.3 & 41.6 & 41.7 & 37.9 & 37.3 & 41.7 & 36.0 & 33.6 & 37.2 & 38.0 & 35.2 & 5.4 & 5.4 \\
\hline South Africa & 4.4 & 5.5 & 5.3 & 4.8 & 5.2 & 5.2 & 5.1 & 5.7 & 6.2 & 4.7 & 6.6 & 11.0 & 15.2 \\
\hline Spain & 19.8 & 17.4 & \begin{tabular}{|l|l|}
18.3 \\
\end{tabular} & 17.5 & 20.1 & 19.5 & 20.5 & 19.7 & 20.4 & 20.3 & 21.4 & 54.8 & 56.1 \\
\hline Sweden & 48.0 & 46.1 & 42.0 & 34.7 & 38.1 & 39.6 & 38.1 & 42.7 & 41.5 & 34.3 & 40.0 & 54.5 & 60.6 \\
\hline Switzerland & 37.4 & 40.0 & \begin{tabular}{|l|}
39.2 \\
\end{tabular} & 39.5 & 38.0 & 40.8 & \begin{tabular}{|l|}
35.9 \\
\end{tabular} & 36.4 & 37.9 & 33.5 & 34.3 & 22.2 & 20.3 \\
\hline UK & 18.4 & 15.1 & \begin{tabular}{|l|}
13.5 \\
\end{tabular} & 17.9 & 15.7 & 17.8 & 18.1 & 18.3 & 17.2 & 18.9 & 20.4 & $\begin{array}{l}63.9 \\
\end{array}$ & 65.1 \\
\hline Ukraine & \begin{tabular}{|l|}
47.5 \\
\end{tabular} & 48.1 & \begin{tabular}{|l|}
47.4 \\
\end{tabular} & 48.6 & 48.1 & 47.2 & \begin{tabular}{|l|l|}
46.2 \\
\end{tabular} & 43.6 & 49.4 & 56.5 & 52.3 & 82.4 & 81.0 \\
\hline USA & 19.4 & \begin{tabular}{|l|}
19.4 \\
\end{tabular} & \begin{tabular}{|l|}
19.7 \\
\end{tabular} & 20.2 & 19.6 & 19.2 & \begin{tabular}{|l|l|}
19.0 \\
\end{tabular} & 19.4 & 19.5 & 19.5 & \begin{tabular}{|l|}
19.7 \\
\end{tabular} & 798.0 & 805.3 \\
\hline TOTAL & & & & & & & & & & & & 2441 & 2490 \\
\hline
\end{tabular}

It is assumed that in 2050 nuclear capacity will be about $1200 \mathrm{GWh}$, providing 24\% of the world electrical supply. The growth of nuclear power is possible due to the rapid transition to standard reactors of the $3^{\text {rd }}$ and $4^{\text {th }}$ generations, as well as to the fast neutron reactors. It will solve the problem of uranium ore security as well as the problem of spent fuel, and increase economic performance and safety of nuclear power plants. It is worth noting that at the plants measures to improve safety taking into account the lessons of the accident at the nuclear power plant "Fukushima" are constantly being provided. The basic element for strengthening nuclear security infrastructure pursued by countries and other relevant organiztions is the IAEA Action Plan on Nuclear Safety [4].

Recently, nuclear power plants are operating in more than 30 countries in the world, and 30 more countries plan to build new nuclear power plants in the near future. The largest number of nuclear power plants is planned to be built in Asia, particularly in China and India. China is considering nuclear energy as an important part of its long-term strategy, seeking to achieve sustainable economic development and the reduction of $\mathrm{CO}_{2}$ emissions. Most of operating power plant units in China are based on nuclear 
technologies from France, Canada, Russia and the USA. Thanks to its experience in the safe and reliable operation of nuclear power plants, and due to testing new reactors of the third generation China may become a global player in the market of nuclear technologies. It is noteworthy that China invests costs in the construction of nuclear power plants all over the world. Thus, the country invests $\$ 9$ billion in nucler power plant construction (Hinkley Point) in the UK, also the Chinese company China National Nuclear Corp. invests \$ 14 billion in construction of the 4th and 5th nucler power plant units in Argentina. On 22 July 2015 Beijing and Tehran signed an agreement to build two nuclear power plants on the southern coast of Iran. Given the success of Beijing on the Iranian market, China can overtake Russia and become its main competitor in Middle Eastern markets. The similar situation is in India, where the share of nuclear energy by 2030 is going to be increased more than in 7 times, i.e. to about $40 \mathrm{GW}$, that will bring the proportion of nuclear energy in the state energy balance to $25 \%$. The experience of Russia where it is planed to build 25 new nuclear units in the near future is important as well. All the 33 units recently working in the country are the socalled open cycle reactors; as the results of their operation radioactive wastes are accumulated. This problem can be solved completely by introducing a new type of reactors that are closed cycle reactors.

A special attention should be given to development of nuclear industry in the EU. In fact, nuclear power, despite the disaster at the Japanese nuclear power plant "Fukushima" is regarded as an ecological source of energy along with renewable energy sources. The importance of nuclear energy is seen in the decisions on the European level accepted by the need to reduce greenhouse gas emissions by $20 \%$ untill 2020 [5].

Today, nuclear energy is the most in Bulgaria, Finland, Czech Republic, Slovenia, Sweden, Belgium, Hungary, Slovakia and France. In these countries the share of nuclear power is $32-77 \%$. Among the EU contries France is the largest nuclear power state, and it is the second in the world after the United States as for the number of active reactors. The country, despite the consequences of the disaster in Japan continues both quantitatively and qualitatively to increase nuclear energy capacity. The first nuclear power plant in France was built in 1956, but only after the oil "shock" in 1970s its nuclear power gradually took the leading place. And a special law adopted on 13 July 2005, assigned to nuclear power the status of the main sources of energy in the country. Due to the end of the lifetime of most nuclear power plants in 2020, the country gradually updates the equipment and actively implements the program of building new generation reactors meeting the requirements of economic competition, environmental protection and increased security.

The country that radically changed the vector of nuclear power development among the developed countries of the EU is Germany. On March 14, 2011, the Chancellor Angela Merkel announced a review of safety standards for German nuclear power plants, and that date is the beginning of a radical change in the development of nuclear energy in Germany. Then the Ethics Commission for a Safe Energy Supply was established, which recommended the country to implement the withdrawal from nuclear power till 2021 and to stop the units. Thus, Grafenrheinfeld Nuclear Power Plant had to be stoped in 2015; Gundremmingen B - in 2017; Phillipsburg 2 - in 2019; Gundremmingen C, and Brokdorf - in 2021; Isar 2, Emsland, and Neckarwestheim - in 2022.

In May, 2011 the government of Switzerland also announced the decision to stop all the units of nuclear power plants in the country till 2034, and not to build the new ones.

The situation in the Eastern Europe is quite opposite. According to available forecasts Poland, Romania, Czech Republic, Slovakia, Bulgaria, Slovenia and Lithuania in certain circumstances can become engines of "nuclear renaissance" in the EU, and the construction of new nuclear power plants would solve several major problems: to get the relatively inexpensive electricity in large volumes, to achieve set environmental standards and to ensure energy security. In May 2014 The European Commission has adopted a new Energy Security Strategy [6]. The development of nuclear energy as key elements of the EU Strategy included:

- Research and development support within the Framework Program "Horizon 2020", including the question of nuclear waste;

- Creation of nuclear energy forum with the participation of all relevant social stakeholders to implement dialogue on the opportunities and risks of nuclear energy;

- Research of $4^{\text {th }}$ Generation Reactors that use less resources and produce less waste.

In December 2015 in Paris during the $21^{\text {st }}$ Session of the Conference of the Parties (COP) of UN Framework Convention on Climate Change [7] the nuclear energy was:

- recognized as a low carbon energy option;

- included alongside other low-carbon technologies to the funding to prevent climate change.

Nuclear fuel production is a complicated, multistage and long process that consists of the following stages: extraction of uranium ore conversion, isotopic enrichment, production. The main uranium (97\%) is concentrated in 16 countries, including Australia - 1706.1 thousand tons, Kazakhstan - 679.3 thousand tons and Russia - 505.9 thousand tons [8]. Stocks of these three countries 


\begin{tabular}{l|lrl|l|ll} 
& ISRA (India) & $=\mathbf{1 . 3 4 4}$ & SIS (USA) & $=\mathbf{0 . 9 1 2}$ & ICV (Poland) & $=\mathbf{6 . 6 3 0}$ \\
Impact Factor: & ISI (Dubai, UAE) $=\mathbf{0 . 8 2 9}$ & PUHЦ (Russia) & $=\mathbf{0 . 2 3 4}$ & PIF (India) & $=\mathbf{1 . 9 4 0}$ \\
& GIF (Australia) & $\mathbf{0 . 5 6 4}$ & ESJI (KZ) & $=3.860$ & IBI (India) & $=\mathbf{4 . 2 6 0}$ \\
& JIF & $\mathbf{1 . 5 0 0}$ & SJIF (Morocco) & $\mathbf{2 . 0 3 1}$ & & \\
\hline
\end{tabular}

account for $50 \%$ of the world's (Table 3 Resources of Uranium).

Table 3

Resources of Uranium [9]

\begin{tabular}{|l|c|c|}
\hline & tonnes Uranium & percentage of world \\
\hline Australia & $1,664,100$ & $29 \%$ \\
\hline Kazakhstan & 745,300 & $13 \%$ \\
\hline Canada & 509,800 & $9 \%$ \\
\hline Russia & 507,800 & $9 \%$ \\
\hline South Africa & 322,400 & $6 \%$ \\
\hline Niger & 291,500 & $5 \%$ \\
\hline Brazil & 276,800 & $5 \%$ \\
\hline China & 272,500 & $5 \%$ \\
\hline Namibia & 267,000 & $5 \%$ \\
\hline Mongolia & 141,500 & $2 \%$ \\
\hline Uzbekistan & 131,100 & $2 \%$ \\
\hline Ukraine & 115,800 & $2 \%$ \\
\hline Botswana & 73,500 & $1 \%$ \\
\hline USA & 62,900 & $1 \%$ \\
\hline Tanzania & 58,100 & $1 \%$ \\
\hline Jordan & 47,700 & $1 \%$ \\
\hline Other & 232,400 & $4 \%$ \\
\hline World total & $\mathbf{5 , 7 1 8 , 4 0 0}$ & \\
\hline
\end{tabular}

All the 447 reactors currently operating in the world, annually consume about 65 thousand tons of uranium. Statistics provided by the World Nuclear Association, assures that the global annual uranium mining increases every year, and in the past few years an average mining is about 58 thousand tons i.e. about $87 \%$ of current world demand. The rest of this raw material is supplemented by stocks (uranium conversion), spent fuel, and imports. The leading uranium miners nowadays are Kazakhstan (39\% of world supply from mines in 2016), Canada (22\%) and Australia (10\%) (Table 4 Production from Mines).

Production from Mines (Tonnes U) [10]

\begin{tabular}{|l|c|c|c|c|c|c|c|c|c|c|}
\hline \multicolumn{1}{|c|}{ Country } & $\mathbf{2 0 0 7}$ & $\mathbf{2 0 0 8}$ & $\mathbf{2 0 0 9}$ & $\mathbf{2 0 1 0}$ & $\mathbf{2 0 1 1}$ & $\mathbf{2 0 1 2}$ & $\mathbf{2 0 1 3}$ & $\mathbf{2 0 1 4}$ & $\mathbf{2 0 1 5}$ & $\mathbf{2 0 1 6}$ \\
\hline Kazakhstan & 6637 & 8521 & 14020 & 17803 & 19451 & 21317 & 22451 & 23127 & 23800 & 24575 \\
\hline Canada & 9476 & 9000 & 10173 & 9783 & 9145 & 8999 & 9331 & 9134 & 13325 & 14039 \\
\hline Australia & 8611 & 8430 & 7982 & 5900 & 5983 & 6991 & 6350 & 5001 & 5654 & 6315 \\
\hline Niger & 3153 & 3032 & 3243 & 4198 & 4351 & 4667 & 4518 & 4057 & 4116 & 4300 \\
\hline Namibia & 2879 & 4366 & 4626 & 4496 & 3258 & 4495 & 4323 & 3255 & 2993 & 3315 \\
\hline Russia & 3413 & 3521 & 3564 & 3562 & 2993 & 2872 & 3135 & 2990 & 3055 & 3004 \\
\hline Uzbekistan (est) & 2320 & 2338 & 2429 & 2400 & 2500 & 2400 & 2400 & 2400 & 2385 & 2404 \\
\hline China (est) & 712 & 769 & 750 & 827 & 885 & 1500 & 1500 & 1500 & 1616 & 1616 \\
\hline USA & 1654 & 1430 & 1453 & 1660 & 1537 & 1596 & 1792 & 1919 & 1256 & 1125 \\
\hline Ukraine (est) & 846 & 800 & 840 & 850 & 890 & 960 & 922 & 926 & 1200 & 1005 \\
\hline South Africa & 539 & 655 & 563 & 583 & 582 & 465 & 531 & 573 & 393 & 490 \\
\hline India (est) & 270 & 271 & 290 & 400 & 400 & 385 & 385 & 385 & 385 & 385 \\
\hline Czech Republic & 306 & 263 & 258 & 254 & 229 & 228 & 215 & 193 & 155 & 138 \\
\hline Romania (est) & 77 & 77 & 75 & 77 & 77 & 90 & 77 & 77 & 77 & 50 \\
\hline Pakistan (est) & 45 & 45 & 50 & 45 & 45 & 45 & 45 & 45 & 45 & 45 \\
\hline
\end{tabular}




\begin{tabular}{|l|c|c|c|c|c|c|c|c|c|c|}
\hline \multicolumn{1}{|c|}{ Country } & $\mathbf{2 0 0 7}$ & $\mathbf{2 0 0 8}$ & $\mathbf{2 0 0 9}$ & $\mathbf{2 0 1 0}$ & $\mathbf{2 0 1 1}$ & $\mathbf{2 0 1 2}$ & $\mathbf{2 0 1 3}$ & $\mathbf{2 0 1 4}$ & $\mathbf{2 0 1 5}$ & $\mathbf{2 0 1 6}$ \\
\hline Brazil (est) & 299 & 330 & 345 & 148 & 265 & 326 & 192 & 55 & 40 & 44 \\
\hline France & 4 & 5 & 8 & 7 & 6 & 3 & 5 & 3 & 2 & 0 \\
\hline Germany & 41 & 0 & 0 & 8 & 51 & 50 & 27 & 33 & 0 & 0 \\
\hline Malawi & & & 104 & 670 & 846 & 1101 & 1132 & 369 & 0 & 0 \\
\hline Total world & $\mathbf{4 1 2 8 2}$ & $\mathbf{4 3 7 6 4}$ & $\mathbf{5 0 7 7 2}$ & $\mathbf{5 3 6 7 1}$ & $\mathbf{5 3 4 9 3}$ & $\mathbf{5 8 4 8 9}$ & $\mathbf{5 9 3 3 1}$ & $\mathbf{5 6 0 4 1}$ & $\mathbf{6 0 4 9 6}$ & $\mathbf{6 2 ~ 8 5 0}$ \\
\hline tonnes $\mathbf{U}_{\mathbf{3}} \mathbf{O}_{\mathbf{8}}$ & 48683 & 51611 & 59875 & 63295 & 63084 & 68976 & 69969 & 66089 & 71343 & 74119 \\
\hline \% of world demand* & $64 \%$ & $68 \%$ & $78 \%$ & $78 \%$ & $85 \%$ & $86 \%$ & $92 \%$ & $85 \%$ & $90 \%$ & $99 \%$ \\
\hline
\end{tabular}

According to the World Nuclear Association [10], in 201511 companies marketed $89 \%$ of world's uranium mine production.

Uranium Minining Companies [10]

Table 5

\begin{tabular}{|c|c|c|}
\hline Company & tonnes $\mathrm{U}$ & $\%$ \\
\hline KazAtomProm & 12681 & 21 \\
\hline Cameco & 10926 & 18 \\
\hline Areva & 9368 & 15 \\
\hline ARMZ - Uranium One & 7849 & 13 \\
\hline CNNC \& CGN & 3303 & 5 \\
\hline BHP Billiton & 3161 & 5 \\
\hline Rio Tinto & 2757 & 5 \\
\hline Navoi & 2385 & 4 \\
\hline Paladin & 1435 & 2 \\
\hline Other & 6631 & 11 \\
\hline Total & 60,496 & $100 \%$ \\
\hline
\end{tabular}

The world price of uranium ore from the mid1970s remains relatively low. However, in general, the uranium price is significantly volatile. The main factors that can influence changes in prices of uranium ore are:

$\square$ the difference between production and consumption. Today, the world demand for raw materials for nuclear fuel production exceeds uranium mining. The difference is covered with recycled materials inventory depletion which by increasing global demand could lead to a dramatic shortage of uranium ore and as a result to a jump in prices; limited stocks of uranium. Given the growing demand for uranium in several countries intending to build nuclear reactors can be concluded that in the next century the world's uranium ore reserves are on the verge of exhaustion that impact its price;

$\square$ construction of new nuclear power plants. The extensive construction of new nuclear power plants increases the demand on uranium fuel;

$\square$ closed uranium market. The structure of the uranium market is very specific. If the majority of metals have stock prices, $90 \%$ of uranium ore is sold under long-term contracts between suppliers and consumers. Only 5-8\% of the uranium ore consumed at power plants is sold in the so-called spot market; $\square$ change in the US dollar rate. The market price for uranium is calculated as the ratio of $1 \$$ per 1 pound. Accordingly, changes in the US dollar rate would change the world market price of uranium;

$\square$ uneven distribution. Uranium ore uneven distribution factor plays an important role in uranium pricing. The exitance of regions with different densities of uranium ore occurrence leads to a specific demand and supply of uranium. Detection of new deposits and the depletion of old ones leads to changes in the market situation, which, in turn, affects the dynamics of price movements.

$\square$ transition to the new technology. The transition to the new fuel cycle technology that allows the use of spent fuel without additional chemical treatment can dramatically change the dynamics of prices for uranium. However, the extensive use of these technologies will become possible about 2020 and complete restructuring of modern system of nuclear power will cause huge material costs;

$\square$ force majeure. One of the clearest examples of the impact of force majeure on uranium market is an accident on October 22, 2006 which caused flooding of Canadian mine Cigar Lake. This led to a 


\begin{tabular}{|c|c|c|c|c|c|c|}
\hline Impact Factor: & $\begin{array}{l}\text { ISRA (India) } \\
\text { ISI (Dubai, UAE } \\
\text { GIF (Australia) } \\
\text { JIF }\end{array}$ & $\begin{array}{l}=1.344 \\
=0.829 \\
=0.564 \\
=1.500\end{array}$ & $\begin{array}{l}\text { SIS (USA) } \\
\text { PИНЦ (Russia) } \\
\text { ESJI (KZ) } \\
\text { SJIF (Morocco) }\end{array}$ & $\begin{array}{l}=0.912 \\
=0.234 \\
=3.860 \\
=\mathbf{2 . 0 3 1}\end{array}$ & $\begin{array}{l}\text { ICV (Poland) } \\
\text { PIF (India) } \\
\text { IBI (India) }\end{array}$ & $\begin{array}{l}=6.630 \\
=1.940 \\
=4.260\end{array}$ \\
\hline
\end{tabular}

sharp drop in uranium mining and a sharp jump in prices.

Since the mid $1990 \mathrm{~s}$ the price of $\mathrm{U}_{3} \mathrm{O}_{8}$ was about $\$ 10$ per pound. From the early 2000 s the price gradually increased and by the end of 2004 rose to $\$$ 20 per pound of uranium concentrate. During 2005 the price on spot contracts increased from $\$ 20$ to $\$$ 35 . In 2006 the growth continued and till the end of the year the level of $\$ 60$ was reached. Then there was an increase from $\$ 75$ to over $\$ 135$ per pound (Figure $2-\mathrm{U}_{3} \mathrm{O}_{8}$ spot price).

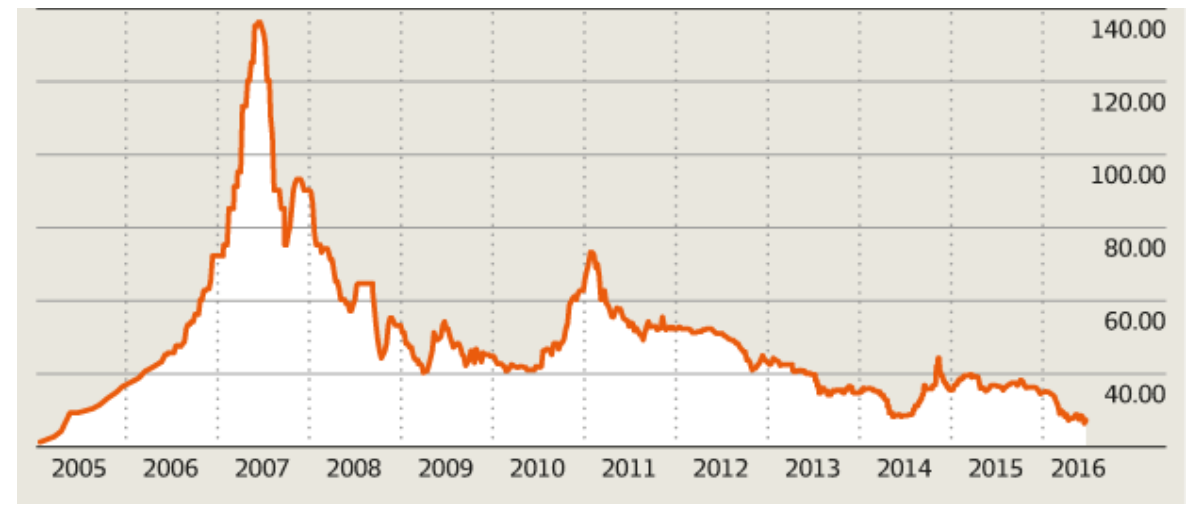

Figure 2 - $\mathrm{U}_{3} \mathrm{O}_{8}$ spot price $[11]$

The rapid rise in prices since mid-2006 reflected consumer concerns regarding lack of raw materials. There was a significant reduction in production in many mines: Canadian McLean Lake (Areva and Cameco) and Rabbit Lake (Cameco), the Namibian RoessingMine (Rio Tinto), Australian Olympic Dam (BHP Biliton) and Ranger (Energy Resourses of Australia). Reduced uranium demand and the incine in the demand increased fears of fuel shortages in the medium term and led to explosive growth in spot price for uranium. At the moment the market price of uranium is calm, but given the market development in the medium term, the world's largest manufacturers have already started implementing a number of projects to increase uranium production. And the success of these projects will influence the dynamics of uranium prices in the near future.

\section{Conclusions}

Having analyzed the general trends of the global nuclear power industry, the following can be concluded:

$\square$ ambitious plans to build nuclear facilities (mainly in China, India, South Korea and Russia) indicate the expansion of its presence in the global energy sector for the foreseeable future;

$\square$ despite certain environmental risks associated with nuclear safety, it could take appropriate competitive position in the energy sector, in most cases due to the relatively positive technical and environmental performance;

$\square$ price of nuclear energy is less dependent on external factors compared to hydrocarbon sources of energy;

$\square$ development of nuclear power in the world is stimulated by the possibility of dual-use of nuclear materials (for power and weapons of mass destruction);

$\square$ nuclear energy is a low-carbon and efficient in terms of costs.

However, despite the obvious objective benefits of the use and development of nuclear energy in general and problems remain, including waste disposal (especially high and radioactive) that complicate further development of this nuclear power industry. Today, there are solutions to these problems, but in most countries consensus on this issue has not been reached yet. Consequently, the uncertainty of the leadership of several countries on the development of nuclear power, a limited supply of information to the public on the pros and cons of nuclear energy, and disturbance as for the inability to prevent the consequences of possible nuclear accidents cause distorted public perception of nuclear energy in general and power plants in particular, and thus inhibit the development of nuclear power engineering. 


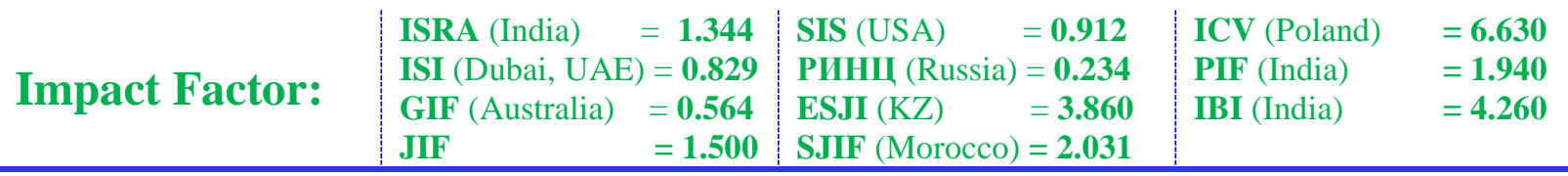

\section{References:}

1. (2017) Annual Energy Outlook 2017. Available: https://www.eia.gov/outlooks/aeo/ (Accessed: 10.05.2017).

2. (2017) World Nuclear Association. Facts and Figures. Available: http://www.worldnuclear.org/information-library/facts-andfigures (Accessed: 10.05.2017).

3. (2017) World Nuclear Association. Facts and Figures. Available: http://www.worldnuclear.org/information-library/facts-andfigures/nuclear-generation-by-country.aspx (Accessed: 10.05.2017).

4. (2017) Action Plan on Nuclear Safety. International Atomic Energy Agency. Available: https://www.iaea.org/newscenter/focus/nuclearsafety-action-plan (Accessed: 10.05.2017).

5. (2017) The European Union Explained. Europe 2020: Europe's growth strategy. Available: http://ec.europa.eu/europe2020/pdf/europe 202 0_explained.pdf (Accessed: 10.05.2017).
6. (2014) Communication from the commission to the european parliament and the council. European Energy Security Strategy /* COM/2014/0330 final $* /$.

7. (2015) Paris Climate Change Conference November 2015. Available: http://unfccc.int/meetings/paris_nov_2015/meet ing/8926.php (Accessed: 10.05.2017).

8. (2009) World Distribution of Uranium Deposits (UDEPO) with Uranium Deposit Classification. IAEA, Vienna.

9. (2016) OECD NEA \& IAEA, Uranium 2016: Resources, Production and Demand ('Red Book').

10. (2017) World Nuclear Association. World Uranium Mining Production. Available: http://www.world-nuclear.org/informationlibrary/facts-and-figures/uranium-productionfigures.aspx (Accessed: 10.05.2017).

11. (2016) Uranium spot prices descend beyond decade low. AFR WEEKEND. Jul.5 2016. 